\title{
Bibliographic and physical organization of non-print materials: with special reference to Sri Lankan special libraries
}

\author{
Anusha Wijayaratne \\ Bsc, MLS, ASLLA, Charted Librarian \\ Assistant Librarian, Open University of Sri Lanka, Nawala, Nugegoda, Sri Lanka \\ Tel: +94-11-2805476 Fax: +94-11-2805476 \\ E-mail: idwij@ou.ac.lk
}

\begin{abstract}
Non-print materials are formats with special characteristics are need to be discussed in terms of bibliographic control and access but often overlooked An ever-increasing amount of information - covering educational and recreational interests - is being produced in a wide range of Non-print formats. As librarians our duty is to provide free and open access to all information regardless of format in which they are stored. This paper, which is based on a research titled 'Organizing practices of non-print materials for access in special libraries of Sri Lanka', provides an overview of the availability of nonprint materials and situation of bibliographic and physical organization of non-print collections together with the librarians' attitudes towards media resources.
\end{abstract}

Keywords: non-print materials/ classification/ cataloguing/ shelf arrangement/ attitudes

\section{Introduction}

Today non-print materials (NPMs) such as audiovisual materials, electronic materials etc, are competing with print material in proliferation. Every day something new and revolutionary emerge in the format of non-print; and the teacher and the librarian alike can no longer think exclusively only in terms of the book. The literature carries a wide range of terms such as non-print materials, non book materials, audio visual materials etc when explaining the different media collections. However, each term has its on limitations. Many professionals have tried to define this term in number of occasions. According to Feather and Sturges "Audio visual materials is a generic term to describe information content held in storage and transmission media and formats that use images and sound rather than or sometimes in addition to textual matter. This includes audio CD, records and tapes; photographs, slides, films and video; and formats that combine two or more of the formats. Many of these formats are out dated now." (Feather and Sturges 2003). However, the non-print resources within the context of this paper include only audiocassettes, videocassettes, motion picture films, slides, microforms and CD ROMs.

"The past ten years of relevant English-language literature includes many publications that stress the importance of providing thorough and consistent cataloging for non print resources" (Ma,1996). Various aspects of non-print materials have been discussed by many LIS professionals through a variety of 
publications namely manuscripts, journal articles, research papers etc. However, there has been no proper survey of the NPMs in Sri Lankan libraries. Therefore, a study to investigate the level of availability (numbers and diversity) of NPMs, the usage of organizing techniques (cataloguing, classification, shelving) and the difficulties encounter by the librarians in organizing NPMs, was very much needed in order to judge our current position in the path of access to information in all formats to all people.

The study was conducted in two phases: preliminary survey and the main survey. The data collection was carried out from February 2003 to September 2003. The aim of the preliminary survey was to identify the sample for the main survey. As there was no updated comprehensive list of libraries, the following sources were used to obtain the contact information of the libraries.

a. Sri Lanka Library Directory (published in 1996 by National Library Services Board)

b. Sri Lanka Telecom Telephone Directory 2003-2004

Altogether 142 special libraries were included in the preliminary survey. The information collected during the preliminary survey were number of items in the non-print collection of the respective library and the types (audiocassettes, videocassettes, CD ROMs etc.) of non-print materials available in their collections.

During the main survey a structured questionnaire was administered to libraries that included more than 100 non-print items in their collections. The questionnaire consisted of 7 main sections namely the details of the library, personal profile of the librarian, resource collection, cataloguing practices, classification practices, shelving practices and librarians' attitudes towards media access. The rate of response was $84 \%$.

Responded libraries were divided in to 3 groups (given in the table 1) in order to identify the effect of number of non-print materials (NPMs) in the collection on the degree of organization.

Table 1 - Grouping of libraries according to the number of NPMs in the collection

\begin{tabular}{|l|l|l|}
\hline Groups & Range of NPMs & Number of Libraries \\
\hline Small size collections & $100-1000$ & 14 \\
\hline Medium size collections & $1001-10000$ & 07 \\
\hline Large size collections & Above 10000 & 05 \\
\hline Total & & 26 \\
\hline
\end{tabular}




\section{Availability of Non-print Materials}

It was seen that non-print collections were few and small in Sri Lanka. The concept of media librarianship is relatively new and particular kinds of collections and materials only since about 1950s. By now audiovisual materials and electronic materials are important as well as popular source of information in most resource collections of special libraries around the world due to their unmatchable merits such as;

- Economy of space - solution for acute storage space of the library.

- Portability and easy to transport

- Monotonous topics made interesting and easy to understand

- Condensation of text helps in quick transmission- there by saving time in learning

- Quick and easy to grasp and remember etc. (CEMCA workshop proceedings, 2002)

However, the situation is not that favorable to non-print materials in Sri Lanka. The preliminary survey revealed that the availability of non-print materials in Sri Lankan special libraries was at a substandard level. According to the findings of the preliminary survey there were only 31 libraries, which included 100 or above non-print items in their collections. The results of the main survey further explained the situation. See table 2.

Table 2 Number and the percentage of libraries in each group

\begin{tabular}{|l|l|l|}
\hline Groups & Number of libraries (n) & Rate\% (n/Nx100) \\
\hline Small Collections Group & 14 & 54 \\
\hline Medium Collections Group & 07 & 27 \\
\hline Large Collections Group & 05 & 19 \\
\hline Total Sample (N) & 26 & 100 \\
\hline
\end{tabular}

According to the findings, the majority of libraries $(54 \%)$ were belonged to category of small collection group, which include 100-1000 non-print items in the collection. All 05 libraries, which include more than 10000 non-print items in the collection, were affiliated to media houses and included exclusively non-print materials, except for very limited number of printed materials. Therefore, the number of libraries that can be considered as multimedia libraries, which include significant number of both non-print materials and printed materials, was 07 . However, the availability value of non-print materials (NPMs) compare to printed materials (PMs) was below $12 \%$, even in those 7 libraries. See table 3. 
Table 3 Comparative availability of NPMs to PMs

\begin{tabular}{|l|l|l|l|l|}
\hline Group & No. of NPMs (n) & No. of PMs & Total (N) & $\begin{array}{l}\text { Rate \% } \\
(\mathrm{n} / \mathrm{N} \times 100)\end{array}$ \\
\hline Small Collections Group & 8014 & 198860 & 206874 & 3.87 \\
\hline Medium Collections Group & 26677 & 196931 & 223608 & 11.93 \\
\hline Large Collections Group & 526880 & 33700 & 560580 & 94 \\
\hline Total & 561371 & 429491 & 991062 & 56.64 \\
\hline
\end{tabular}

List of libraries in each category is given in the Annex -1 .

\section{Availability of Types of Non-print Materials}

Only 6 types of non-print materials were included in at least $10 \%$ of sample libraries. They were audiocassettes $(A)$, videocassettes $(V)$, motion picture films (MP), slides (S), microforms (MF), CD-ROMs (CD). Videocassettes, audiocassettes and CD-ROMs were the dominant non-print formats in Sri Lankan Special libraries. See table 4.

Table 4 Availability of types of NPMs

\begin{tabular}{|l|l|l|l|l|l|l|}
\hline Group & A & V & MP & S & MF & CD \\
\hline Small Collections Group & 1297 & 1306 & 543 & 1452 & 329 & 2983 \\
\hline Medium Collections Group & 5259 & 9421 & 138 & 5181 & 2500 & 1173 \\
\hline Large Collections Group & 247900 & 141000 & 1055 & 1300 & 3000 & 6218 \\
\hline Total & 245456 & 151727 & 1736 & 7933 & 5829 & 10374 \\
\hline
\end{tabular}

\section{Cataloguing Practices of Non-print Materials}

Cataloguing of non-print materials has specific difficulties other than the common difficulties of cataloguing such as multilingual and multiscript issues. The spectrum of non-print materials is wide and complex. Inconsistencies in publications are causing serious problems in tracing bibliographic information (lack of definite source like title page of the book). In addition, cataloguing audiovisual and electronic formats needs external machinery support to browse through the program to find the necessary details. However, the librarians are trying hard to overcome these difficulties and organizing all formats of materials in their collections to enhance the usage. 
The findings of the survey clearly showed the commitment of librarians in organizing their collections, despite of many obstacles such as lack of skilled staff, budgetary constraints, lack of support and recognition from authorities etc. Around $70 \%$ of the surveyed libraries had catalogued their non-print materials while almost $100 \%$ of them catalogued their printed materials. In addition, cataloguing of non-print materials showed significant increase with increasing number of materials in the collection. See figure 1.

Fig. 1 Number of NPMs in the collection Vs application of cataloguing practices

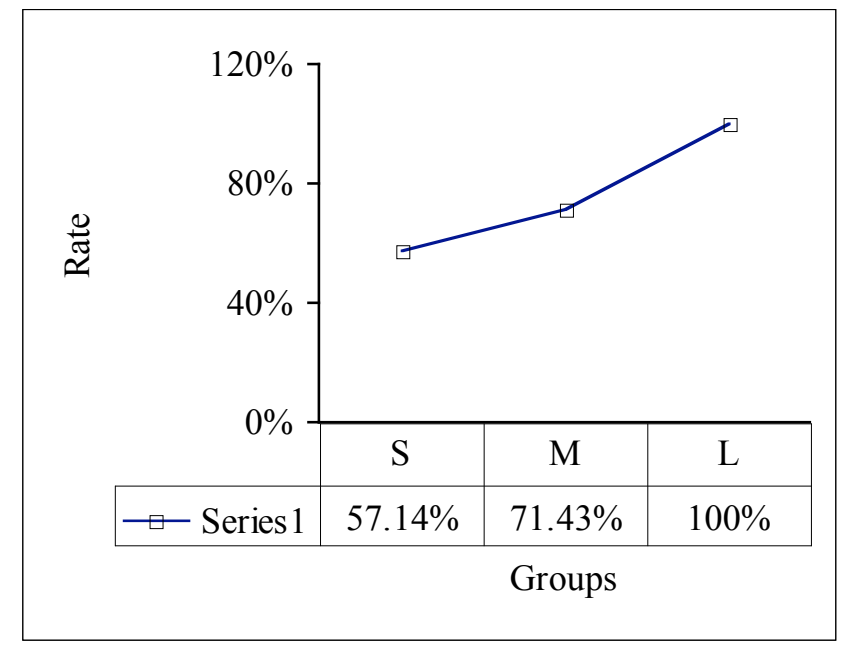

S Small collections group

M Medium collections group

L Large collections group

\section{Usage of Cataloguing Rules}

In cataloguing, standards play a key role in maintaining uniformity institutionally, regionally, nationally or internationally. "Major overhauls in cataloging rules have taken place since the development of non-print collections in libraries. Rule changes have helped to create logical conventions for describing non-print items. For example Anglo-American Cataloguing Rules, second edition (AACR2), chapter 9 was revised to include machine-readable data files" (Kaye, 1991). In addition, there are cataloguing codes dedicated to non-print as such as The FIAF Cataloguing Rules for Film Archives, Guidelines for Bibliographic Description of Interactive Multimedia (American Library Association), the IASA cataloguing rules: a manual for description of sound recordings and related audiovisual media etc.

In-house cataloguing codes seemed to be more popular than the standard cataloguing codes among the special libraries in cataloguing non-print materials. 
AACR2 was the only standard cataloguing code used by the libraries that were selected for the survey - small collection group (87.5\%) and medium collection group $(60 \%)$ - while all the libraries in the large collection group used in-house cataloguing codes. In addition, the usage of AACR2 for non-print materials (NPMs) was below the usage of printed materials (PMs) in all three groups. See figure 2

Fig. 2 Usage of AACR2 for NPMs compared to PMs

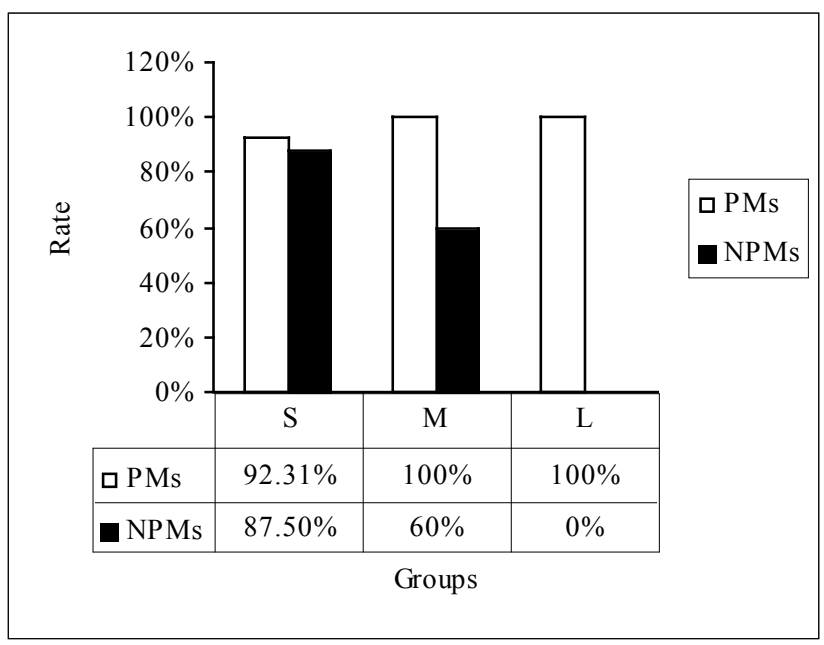

S Small collections group

M Medium collections group

L Large collections group

\section{Formats of Catalogues}

Survey findings revealed the present trend of computerizing the library functions particularly the library catalogues. The most popular type of catalogue format was the computer catalogue. $70 \%$ of the responded libraries had computerized catalogues for non-print materials. See figure 3. 
Fig. 3 Formats of catalogues

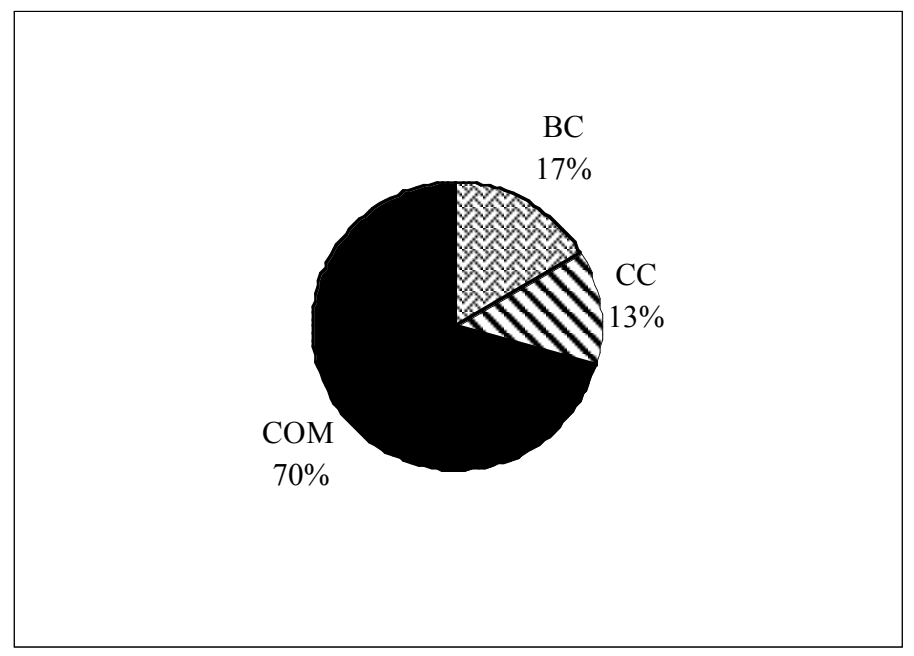

BC- Book Catalogue, CC card Catalogue, COM- Computer Catalogue

\section{Classification Practices of Non-print Materials}

IT is said that, "The role of classification in information retrieval is often assigned to subject attributes of documents" (Knowledge Organization for Information Retrieval Proceedings, 1997). In other words, suitability of the classification system to a particular collection of resources entirely depends on the subject spectrum. So there are no barriers to classifiers to use the same classification system for both print materials as well as non-print materials.

The survey findings on application of classification schemes clearly showed that librarians of small collections group and medium collections group had given priority to classify printed materials over non-print materials. However, the application of classification systems to non-print materials increased with number of non-print materials in the collection. See figure 4. 
Fig. 4. Classification of NPMs compared to PMs

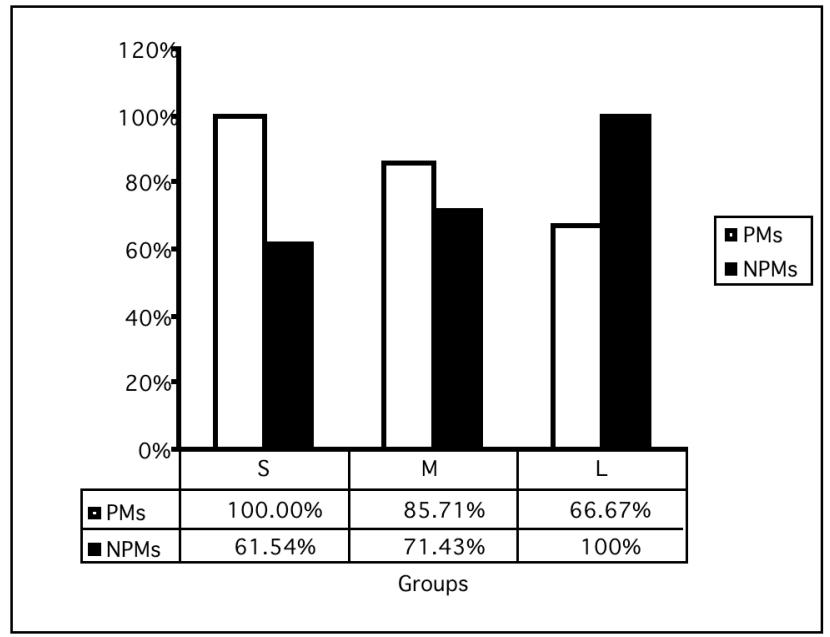

\section{Usage of Classification Schemes}

Usage of standard classification schemes (Dewy Decimal Classification and Universal Decimal Classification) to classify printed materials was always at a very high level. However, the situation was different for non-print materials. Only the libraries of small collections group (75\%) and medium collections group $(20 \%)$ had applied standard classification schemes to classify non-print materials while all the libraries in the large collection group used in-house classification schemes. Further, no library has used an in-house classification scheme for printed materials. See figure 5.

Fig.5. Usage of Standard Classification Schemes for NPMs Compared to PMs

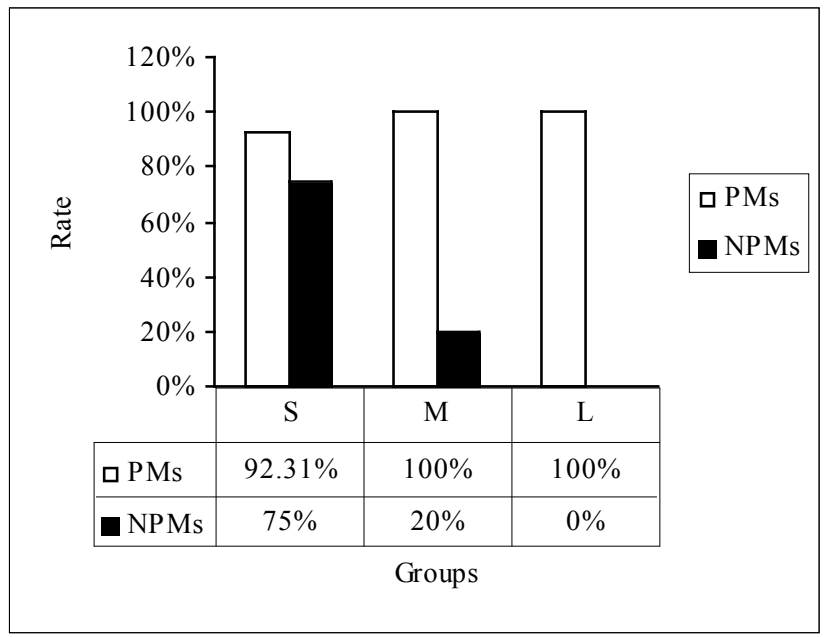
S Small collections group
M Medium collections group
L Large collections group 


\section{Shelving Practices of Non-print Materials}

Intershelving non-print materials with other materials enhances the usage as it provides opportunity to locate valuable materials that might otherwise be kept in shielded. However, the complete integration is not possible due to various reasons such as the non-conformity of shapes, fragile in nature etc. Partial integration is possible and is recommended for materials, which could be packaged like books. Placing dummies to represent non-print materials in the book collection, is popular among European countries as it not only allows to store the fragile non-print materials safely while ensuring the effect of intershelving but it also allows to convey the message on existence of non-print materials such as online journals that cannot be physically displayed. However, according to the survey findings, any form of intershelving is not in practice among the special libraries of Sri Lanka.

\section{Pattern of Access of Non-print Materials}

Accessibility is another major issue for the librarian to consider in the physical arrangement of non-print materials. Some libraries prefer closed access in order to ensure adequate security, prevent constant handling and consequent damage. Others prefer open access as it is self-advertising and thereby draws the attention of patrons who may not be aware of their existence (Lawal, 2002). The present trend is, however, towards open access, which facilitates partial integration and discourages the erroneous belief that non-print resources are special materials, which need special treatment.

The situation among Sri Lankan special libraries is not very discouraging as significant percentage of libraries provides open access to non-print materials. According to the survey findings the percentages of libraries (out of 26 responded libraries) that provide open access to selected types of non-print materials are as follows; audiocassettes (56\%), videocassettes (50\%), Slides $(40 \%)$ and CD ROMs (42\%). In addition, certain formats of non-print materials are available for loan in significant percentage of libraries particularly, audiocassettes (74\%), videocassettes (70\%), motion pictures $(67 \%)$.

There is no gainsaying that non-print resources, because of their physical nature, need adequate protection to prevent loss and damage. The ultimate aim is to ensure the maximum utilization of the resources and at the same time ensure their safety (Lawal, 2002). 


\section{Librarians' Attitudes Towards Media Access}

Attitudes are not easy to change but can be improved and developed through experiences and education. Positive attitudes are needed more than any thing else for the success of any effort.

The following attitudes were investigated in the attitudinal survey, which was participated by 26 librarians who responded the main survey;

- Desirability of equal bibliographic treatment for all materials.

- Desirability of equal physical access to all materials.

- Perception of the cost of non-print materials

The results of this attitudinal survey of librarians of special libraries were clearly in favour of integrated bibliographic access as $64 \%$ of surveyed librarians agree to the statement "I want to see entries for every thing in the library in one catalogue" while just 33\% agree to the statement "Each medium should have its own catalogue". In addition, $59 \%$ of them disagreed to the statement "It is difficult to apply AACR2 to non-print materials."

However, there were only 2 librarians showed their interest towards physical integration in the form of partial intershelving. However, $65 \%$ of librarians approved open access to non-print materials.

In general, around $60 \%$ of librarians who were involved in the survey believed the costs of non-print materials were affordable by their libraries. However, $72 \%$ of them stated that they need more funds in order to develop non-print collections and maintain reference services for users.

\section{Discussion and Conclusion}

The researcher visited over $80 \%$ of libraries in the sample and talked to the librarians personally. Most of the libraries did not have a suitable environment, space, storage devices or equipments to develop and maintain healthy non-print collection.

Preliminary survey revealed that the availability of NPMs in Sri Lankan special libraries was in a disastrous level. Only 31 libraries out of the total of 142, possessed more than 100 non-print items. Further, the majority of them belonged to the small size collections group (100-1000). There were only 07 libraries (medium size collections group -1000-10,000) that can be considered as multimedia libraries, which included significant portion of both formats, printed and non-print.

Application of cataloguing and classification techniques to NPMs demonstrated somewhat similar pattern of behaviour. Both techniques showed significant 
improvement with the increment of number of NPMs in the collection. However, the level of classification as well as the level of cataloguing of NPMs was always below that of printed materials.

Shelving NPMs for easy access seems to be the area that received the least attention of librarians out of the three, organizational practices surveyed. Number of libraries providing close access exceeded the number of libraries providing open access to all materials except for audiocassettes and videocassettes. However, librarians were not strongly against the idea of lending such materials.

The researcher tried to identify the reasons for this unsatisfactory status of classification, cataloguing and shelving of NPMs through observations and oral conversations with librarians. Lack of funds, shortage of skilled staff, difficulty in tracing bibliographic information, small size, fragile nature, and absent of proper environment are the major constraints.

The lack of proper training on non-print media was another significant factor that retarded the growth of multimedia libraries in Sri Lanka. Over $80 \%$ of participants responded negatively to the question that asked for the participation of special training programs or workshops on non-print media.

The meeting the needs of users in information society with only printed materials is impossible and ineffective. Therefore, we should take immediate steps to eliminate the barriers to ensure that our clientele enjoy their share of information in spite of the format they stored. The government, authorities of parent organizations and institutions who involve in library education can play a vital role for the development of media librarianship in Sri Lanka by providing physical resource and empowering the library staff with skills and knowledge. Above all librarians should motivate themselves to face the challenges for the sake of our clientele.

\section{References}

- Non-print media library management. Commonwealth Education Media Centre for Asia (CEMCA) workshop handout. New Delhi, 1997

- Feather, John and Sturges, Paul (2003). International encyclopedia of information and library science. $2^{\text {nd }}$ ed. London. Routledge

- Kaye, Alan L (1991). Video and other nonprint resources in the small library. American Library Association

- Lawal, L.D. (2002). The effective organization and utilization of non-print resources. Library Review, 46(3), pp. 210-215

- Ma, Yan [et al]. (1996). Cataloging nonprint resources in the United States and China: A comparative study of organization and access for selected electronic and audiovisual resources. [online]. (URL http://www.ifla.org...). Accessed on 20.03.2003. 
- The Role of Classification in the Creation of Author and Work Displays in Online Catalogs Knowledge Organization for Information Retrieval, Proceedings of the Sixth International Study Conference on Classification Research. London, 1997 


\begin{tabular}{|c|c|c|}
\hline $\begin{array}{l}\text { Libraries - small } \\
\text { collections group }\end{array}$ & $\begin{array}{l}\text { Libraries - medium } \\
\text { collections group }\end{array}$ & $\begin{array}{l}\text { Libraries - large } \\
\text { collections group }\end{array}$ \\
\hline $\begin{array}{l}\text { Arthur C. Clarke Centre for } \\
\text { Modern Technologies } \\
\text { (ACCMT) - Library } \\
\text { Moratuwa }\end{array}$ & $\begin{array}{l}\text { American Information \& Resource } \\
\text { Centre, Colombo }\end{array}$ & $\begin{array}{l}\text { D.R. Wijewardena } \\
\text { Memorial Library } \\
\text { Colombo }\end{array}$ \\
\hline $\begin{array}{l}\text { Atomic Energy Authority } \\
\text { (AEA) - Library } \\
\text { Wellampitiya. }\end{array}$ & $\begin{array}{l}\text { Alcohol and Drug Information } \\
\text { Centre (ADIC) - Library } \\
\text { Colombo }\end{array}$ & $\begin{array}{l}\text { Independent Television } \\
\text { Network - Library } \\
\text { Battaramulla }\end{array}$ \\
\hline $\begin{array}{l}\text { Automobile Engineering } \\
\text { Training Institute - Library } \\
\text { Wellampitiya }\end{array}$ & $\begin{array}{l}\text { British Council Information \& } \\
\text { Language Centre - Colombo } \\
\text { Colombo }\end{array}$ & $\begin{array}{l}\text { MTV Channel (Pvt.) LTD } \\
\text { - Library } \\
\text { Pannipitiya }\end{array}$ \\
\hline $\begin{array}{l}\text { Central Bank of Ceylon } \\
\text { Research Library } \\
\text { Colombo }\end{array}$ & $\begin{array}{l}\text { British Council Information \& } \\
\text { Language Centre - kandy } \\
\text { Kandy }\end{array}$ & $\begin{array}{l}\text { Sri Lanka Broadcasting } \\
\text { Cooperation - Library } \\
\text { Colombo }\end{array}$ \\
\hline $\begin{array}{l}\text { Centre for Industrial } \\
\text { Technology Information } \\
\text { Service (CITIS) - Library } \\
\text { Moratuwa }\end{array}$ & $\begin{array}{l}\text { Ceylon Tourist Board - Library } \\
\text { Colombo }\end{array}$ & $\begin{array}{l}\text { Sri Lanka Rupavahini } \\
\text { Corporation - Library } \\
\text { Colombo }\end{array}$ \\
\hline $\begin{array}{l}\text { Charted Institute of } \\
\text { Management Accounts - } \\
\text { Library, Colombo. }\end{array}$ & $\begin{array}{l}\text { Lanka Jathika Sarvodaya } \\
\text { Shramadana Sangamaya Library } \\
\text { Moratuwa }\end{array}$ & \\
\hline $\begin{array}{l}\text { Institute of Computer } \\
\text { Technology - Library } \\
\text { Colombo }\end{array}$ & $\begin{array}{l}\text { National Museum Library } \\
\text { Colombo. }\end{array}$ & \\
\hline $\begin{array}{l}\text { Institute of Fundamental } \\
\text { Studies (IFS) - Library } \\
\text { Kandy. }\end{array}$ & & \\
\hline $\begin{array}{l}\text { J. R. Jayawardene Cultural } \\
\text { Centre Library, Colombo. }\end{array}$ & & \\
\hline $\begin{array}{l}\text { National Film Archival Library } \\
\text { Kelaniya }\end{array}$ & & \\
\hline $\begin{array}{l}\text { National Institute of Business } \\
\text { Management (NIBM) - Library } \\
\text { Colombo. }\end{array}$ & & \\
\hline $\begin{array}{l}\text { National Institute of Education } \\
\text { Library and Information } \\
\text { Division, Maharagama }\end{array}$ & & \\
\hline $\begin{array}{l}\text { National Institute of Technical } \\
\text { Education - Library } \\
\text { Ratmalana. }\end{array}$ & & \\
\hline $\begin{array}{l}\text { The World Conservation } \\
\text { Union - Library } \\
\text { Colombo. }\end{array}$ & & \\
\hline
\end{tabular}

